\title{
Families in the Household Registers of Seventeenth-Century Korea: Capital, Urban and Rural Areas ${ }^{1}$
}

DONGGUE LEE Senior Researcher, Academy of East Asian Studies, Sungkyunkwan University $^{2}$

SANGWOO HAN Postdoctoral Researcher, Universitat Autònoma de Barcelona ${ }^{3}$

\begin{abstract}
Because of the Japanese (1592-1598), and Manchu (1627, 1636-1637), invasions, the seventeenth century was a turning point in the Neo-Confucian transformation of Chosŏn dynasty. Changes and continuities in Korean society and families can be seen in household registers published in the seventeenth century. Occupational records and family structures from the top to the bottom of society show that social hierarchies and governmental systems were well preserved even after the invasions. This study also highlights the value of household registers as a primary historical source for the study of Korean social and family history.
\end{abstract}

Keywords: family history, social hierarchy, household register, seventeenth century, occupational record, Confucian transformation

\section{Introduction}

This study focuses on individuals and families in seventeenth-century Korea in order to understand the dynamics of Korean family and society during a period of change. The seventeenth century is usually taken as the dividing line EUROPEAN JOURNAL OF KOREAN STUDIES, VOLUME 20, NO. 1 (2020), pp. 1-34. 
between early and late Chosŏn. Because the majority of early Chosŏn rulers and political elites were rooted in the former Koryŏ dynasty (918-1392), the main characteristics of Chosŏn society were still quite similar to those of the Koryŏ dynasty until sometime in the sixteenth century. However, the Japanese and Manchu invasions (1592-98, 1627, and 1636-37), triggered social changes, which accelerated the Neo-Confucian transformation of Chosŏn society. ${ }^{4}$ Although we cannot elaborate what constituted a "Confucian transformation" beyond greater emphasis on continuity of elites, and social hierarchy, we can note that these trends not only survived the Japanese and Manchu invasions, they were strengthened. Household registers offer a concrete, positivist approach to research on social change, and the main purpose of this study is to highlight the use and value of household registers.

One of the best ways to understand society and families in pre-modern Korea is to use household registers. The government ordered local authorities to compile household registers every three years, which recorded households according to residence. The registers contained information about each household member: their relationship with the head of household, their occupational record (職役), and their age. "Occupational record” in the registers was not only related to real occupations but was also a reference to the kinds of duties owed to the government by the king's subjects. As we see below, occupation also included place of origin, either Japan or Manchuria. Therefore, household registers provide copious material for understanding the characteristics and structure of the family and the homogeneity of the local community.

The following aims to demonstrate the usefulness of the household registers of Chosŏn as credible historical data for case studies of families. Quantitative research using data from household registers began after the digitization of the Tansŏng registers twenty years ago. ${ }^{5}$ The digitization of the household registers of Taegu, one of the few cities in Chosŏn at that time, was completed in 2019. The digitization of the Ulsan register will be completed soon. Here, we explore the possible applications of these digitized registers by presenting various examples of seventeenth-century registers during a turning point in Chosŏn history and the Confucian transformation of Korea.

Pre-modern Korean household registers are particularly useful, because they include information on a wide variety of people from the top and bottom of the societal hierarchy. In this study, we introduce royal family members, government officials, and their family members in seventeenth-century household registers. The inclusion of elites is a unique feature of the Korean household registers, which contrast with neighboring Japanese population registers. Hamano Kiyoshi, a Japanese historical demographer, notes that historically notable figures are 
rarely seen in the pre-modern Japanese population registers, the shümon aratame cho (宗門改帳). ${ }^{6}$ This paper will also describe the presence of local administrative professionals, commoners with unique occupations, and nobi ${ }^{7}$ in seventeenthcentury Korean household registers after the Japanese invasions.

The Chosŏn household registers contain information on the current age, birth year, family relationship, and occupation of hundreds of thousands of individuals. They have been useful for quantitative researchers working on population history and historical demography. In particular, researchers have attempted to ascertain the marriage age and child birth rate from these registers by region and by class. ${ }^{8}$ These studies belong to the field of family history and are aimed at comparing the form and specificity of individuals and families in the late Chosonn period with other parts of the world. ${ }^{9}$ In this study, we expand the use of the household register into qualitative research by introducing certain key types of individuals and those who had unique occupations.

The first section will introduce the household registers and provide historical background information about seventeenth-century Korean society. The second section focuses on royal family members, bureaucrats, and their families through the household register of the capital city, Seoul. The third section analyzes the administrative and military cities of Taegu and Ulsan in order to describe local headmen, low-ranking military officials, and immigrants from outside of the Korean peninsula. In the fourth section, we investigate the rural areas of Tansŏng, San'ŭm, Ich'ŏn, and Haenam to illuminate the family lives of local elites, commoners with unique occupations, and nobi. The main findings of this study look to the household registers after the Imjin War to present examples of continuities and changes in social hierarchies, revenue systems, and ethnic integrity.

\section{Seventeenth-Century Korea and the Household Registers}

Historians agree that the massive impact of the Japanese invasions caused significant changes in Korean society. Toyotomi Hideyoshi, the Japanese hegemon, who had unified Japan after a period of instability, invaded the Korean Peninsula in the fourth lunar month of 1592 intending to conquer China. However, due to the successful resistance of Chosonn troops and the participation of the Ming Chinese army, his attempt failed. The war ended in the eleventh lunar month of 1598, following Hideyoshi's death in the eighth lunar month. A little-appreciated aspect of the invasion is the fact that the social and political structures survived an assault that could have resulted in widespread revolt and a radical change in the ruling elite. 
The Chosŏn government succeeded in recovering from the demographic and economic devastation of the seven-year war, and the social tenets of Confucianism became a useful ideological tool. King Sŏnjo and his government actively employed Confucian rhetoric to avoid responsibility for their diplomatic and military failures before and during the war. Rather than acknowledge the role played by the Korean population in defeating the Japanese, the court emphasized Ming China's role in sending troops to rescue the nation. As an extension of creating a Confucian rhetorical project, the court tried to reinvent a state that expressed gratitude to the Ming emperor Wanli, who was considered to be at the top of the Sino-centric world. By expressing absolute obedience to the Ming, the Chosŏn government described their project as a “remaking (再造)" of the state. ${ }^{10}$

The subsequent invasions by the Manchus in 1627 and 1636-1637 accelerated further social change. Over the first three decades of the seventeenth century, the Ming dynasty was significantly weakened. The people of the Manchu state were able to strengthen their military power and after two successful invasions of Korea eventually occupied the Ming capital of Beijing in 1644. Succumbing to the Manchu invasions, the Chosŏn dynasty found themselves serving the Manchu people as their new suzerain state. From the Koryŏ-period confrontations with the Khitan-Liao, the Jurchen-Jin, and the Mongols, the northern tribesmen, and especially the Manchus, had been perceived to be barbarians and even more so later, when compared to the Confucian societies of the Chosŏn and Ming dynasties. Chosŏn Confucian elites, who could not admit the sovereignty of the Manchus, considered themselves as a "little China," or as the inheritor of the Confucian tradition. This de-centering of China and redefinition of Korea's role accelerated the Confucian transformation of Chosŏn society, even at the family level. ${ }^{11}$

Below the macro politics of state survival, the survival of the antebellum social order and its bolstering through Confucian rhetoric and ritual was quite striking. By volunteering as patriotic militia leaders in the war, Confucian elites were able to present an air of moral superiority and consolidate their authority and legitimacy in local society. After the war, elites resurrected their exalted status by emphasizing local elite association rosters (hyangan, 鄉案), at the county level in addition to community compacts (hyangyak, 鄉約 or tongyak, 洞約). ${ }^{12}$ The propagation of community or village compacts started in the sixteenth century, but the increased emphasis in local areas on community compacts and local elite association rosters became prominent after the Imjin War. The result was that the social reputation and role of the elite were strengthened after the war. Through this process, Confucian ritual and rhetoric further penetrated the lives of the elites and defined their identity even more. ${ }^{13}$ 
By examining household registers of various regions of Korea in the seventeenth century, we can understand how the Chosŏn Dynasty recovered from the wars against Japan and the Manchus in the sixteenth and seventeenth centuries. The degree of devastation should be borne in mind. Before the wars, the Chosŏn dynasty contained 1.708 million $k y{ }^{\prime 14}$ of farmland, but this figure dropped to less than 0.542 million kyŏl after the war. ${ }^{15}$ In Kyŏngsang Province, a major battleground of the Imjin war, 89 percent of total arable land was damaged, declining from 400,000 kyŏl before the war to 43,400 kyŏl in $1603 .{ }^{16}$ The impact of the invasions may also be understood by considering the number of Koreans taken captive during the wars. In 1591, the population of the Korean Peninsula was about 10 to 14 million. ${ }^{17}$ Historians argue about the number of captives, believed to be between $20,000^{18}$ and $400,000^{19}$ during the Japanese invasions and as many as 500,000 during the Manchu invasions. ${ }^{20}$ The number of captives alone, excluding deaths, could have amounted to about 4 to 6 percent of the total population. This drastic demographic decrease brought significant change to the political, social, and cultural systems of the Chosŏn dynasty that lasted centuries. Despite the political, economic, and social instability caused by the war, the Chosŏn government tried to reconstruct a collapsed state system in order to solidify the post-war dynasty.

In such a historical context, this study will consider people of varied social statuses who had unique occupations. We, therefore, paid attention to the Chosŏn household registers published in the seventeenth century. The Chosŏn government stipulated that local governments should compile household registers every three years. However, after several invasions and wars, only a few household registers published in the seventeenth century remain. This study uses ten household registers compiled by seven counties between 1606 to 1687, which constitute some of the earliest extant Korean household registers. Each household register provides useful personal information for family and historical demographic studies. The registers organized residents by administrative household units and recorded their name, age, relation to the household head, occupational record, and place of origin of the family. The registers also traced lineages by recording the names of each individual's mother, "four fathers" (father, grandfather, great grandfather, and maternal grandfather), and adoptive father (when appropriate). For nobi, the residence, occupation, and name of their master were recorded.

The Chosŏn government divided the Korean Peninsula into eight do (道, provinces), and placed $p u$ (府, prefectures, usually with a defense command), kun (郡, district), and hyŏn (縣, small county) under it. Within large and small counties were myŏn (面, townships), which were divided into several ri (里), and kye (契), administrative villages, which actually included several natural villages. The 
Table 1 Household registers for analysis in this study

\begin{tabular}{|l|l|l|l|l|}
\hline No. & District & Household registers & Categories & Computerized \\
\hline 1 & San'úm & 1606,1630 & Rural & \\
\hline 2 & Tansŏng & 1606,1678 and more & Rural & completed (open for public) \\
\hline 3 & Ulsan & 1609,1672 and more & military city & Partial (open for public) \\
\hline 4 & Haenam & 1639 & Rural & \\
\hline 5 & Seoul (Hansŏng) & 1663 & capital city & completed (personal use) \\
\hline 6 & Taegu & 1681,1684 and more & provincial capital & completed (open for public) \\
\hline 7 & Ich'ŏn & 1687 & Rural & \\
\hline
\end{tabular}

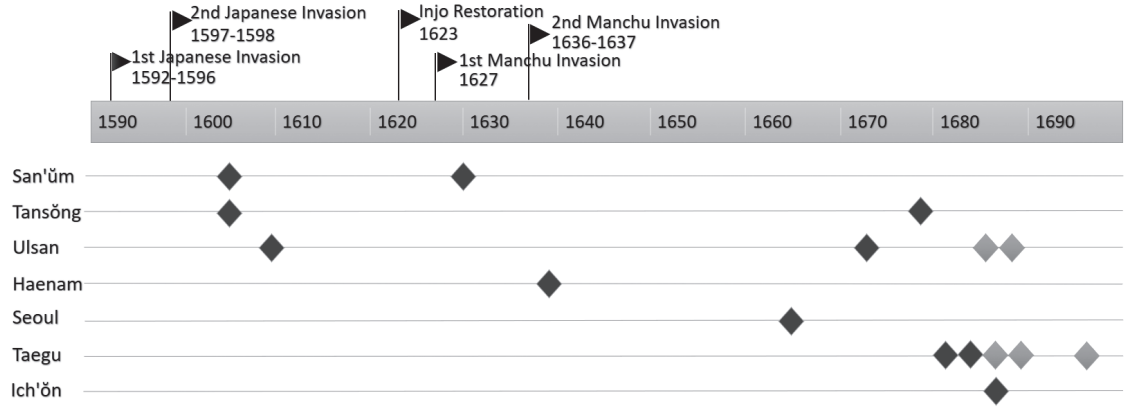

Figure 1 Timeline of political events and household registers of seventeenth-century Korea

Note: The dark diamonds in Figure 1 represent the registers used in this article.

household registers were published at the township level and reported to the local and central governments. Table 1 shows the household registers that are used in this study; Figure 1 shows a timeline of political events and the chronological and geographical positions of the seventeenth-century household registers, and Figure 2 shows the geographic location of the registers. We used all the digitized household registers and most of the extant, undigitized registers published in the seventeenth century. ${ }^{21}$ 


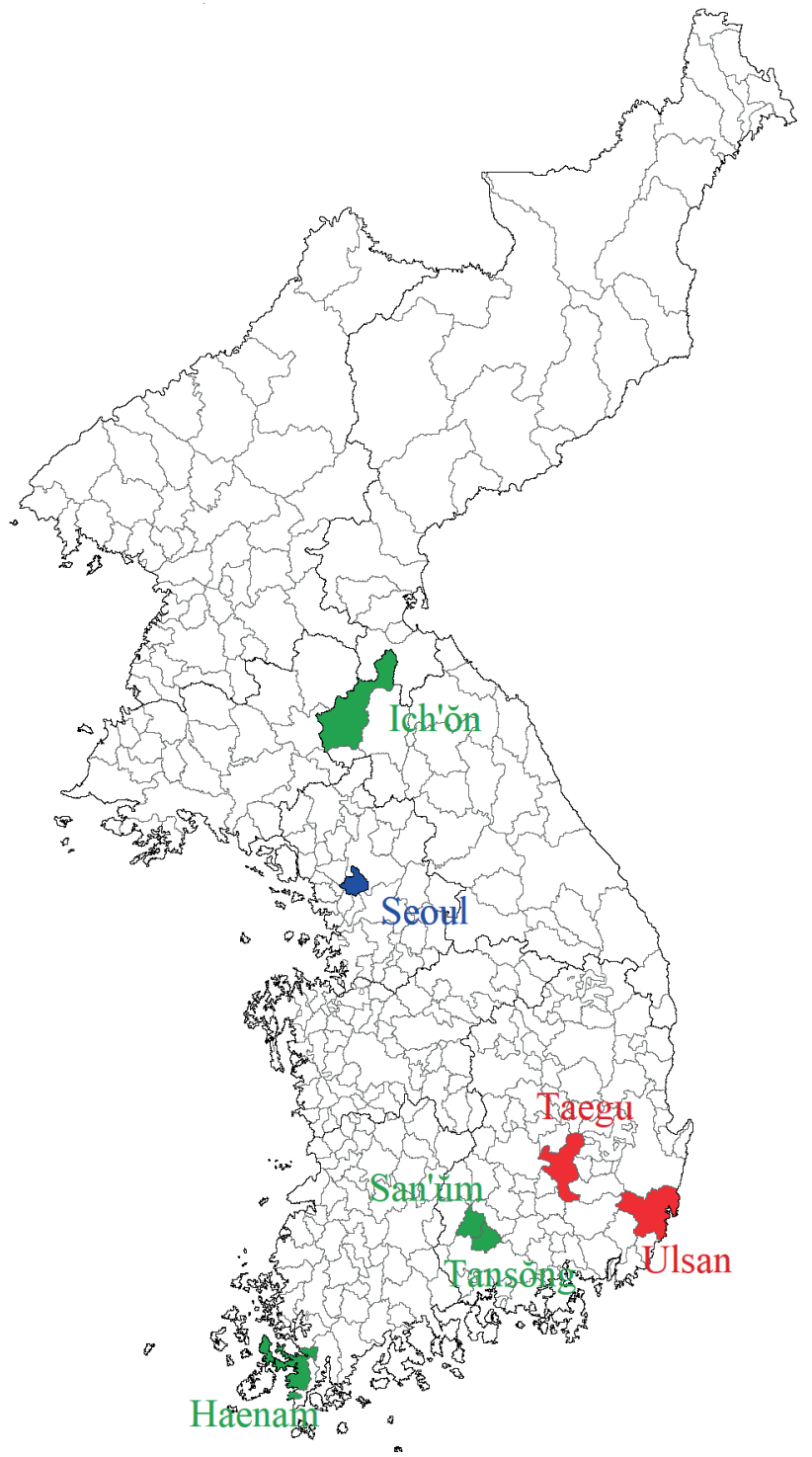

Figure 2 Map of the household registers used in this study 


\section{The Capital, Seoul}

Seoul has been the capital of all governments on the Korean Peninsula from 1394 until the present day. Thus, Seoul has been regarded as the administrative, economic, and cultural center of the Korean Peninsula for more than 600 years. However, the only remaining household register of Seoul before the twentieth century is from 1663. As a result, researchers have spotlighted this household register as a primary source of historical information. ${ }^{22}$ However, the digitization of the register was only recently completed. ${ }^{23}$

The 1663 Seoul household register did not cover the entire city, but instead recorded only the northern district (北部), of the city, especially outside of the city wall. This area is now located in Mapo-gu and Sŏdaemun-gu, at the center of the modern Seoul metropolitan area. This family register for the northern district totaled only 4,759 individuals in 683 households (averaging 7 people per household). Among the surviving population records of Seoul, the closest in date to this household register from 1663 is a general survey conducted in 1672. The Capital District Office (Hansŏngbu, 漢城府), reported to the king in 1672 that the total number of households in the capital was 24,800 , so the 1663 household register represents only 2.75 percent of the total number of households. ${ }^{24}$ However, household registers tended to record only about 60 percent of the total population, and estimates for the actual population of Seoul at that time puts the total closer to $300,000 . .^{25}$ The following examines royals, bureaucrats, and eunuchs who appear in the 1663 Seoul household register.

\section{Royal Family Members}

We found 18 royal family members in the 1663 household register. The Chosŏn government recognized royal family members as descendants of a king up until the fourth or fifth generation and awarded them various favors. The register classified them differently by marking them as "royal family" and by not recording their family name, $\mathrm{Yi}^{26}$

The royal family members sampled for this article were not close enough to share personal relationships with the king. Although some kings sometimes took an interest in them, most would only encounter the king at royal ceremonies. It should also be noted that royal family members were sometimes executed or exiled for their involvement in rebellion or oppositional political events. We will introduce some specific examples of royal family members who met this fate.

Among the 11 households recorded in Yangch'ollli-kye, five households were royal descendants of the 11th king, Chungjong (1506-1544), and his second son, Prince Haean (1511-1573). Yi Wŏnch'ung, the household head of the first household 


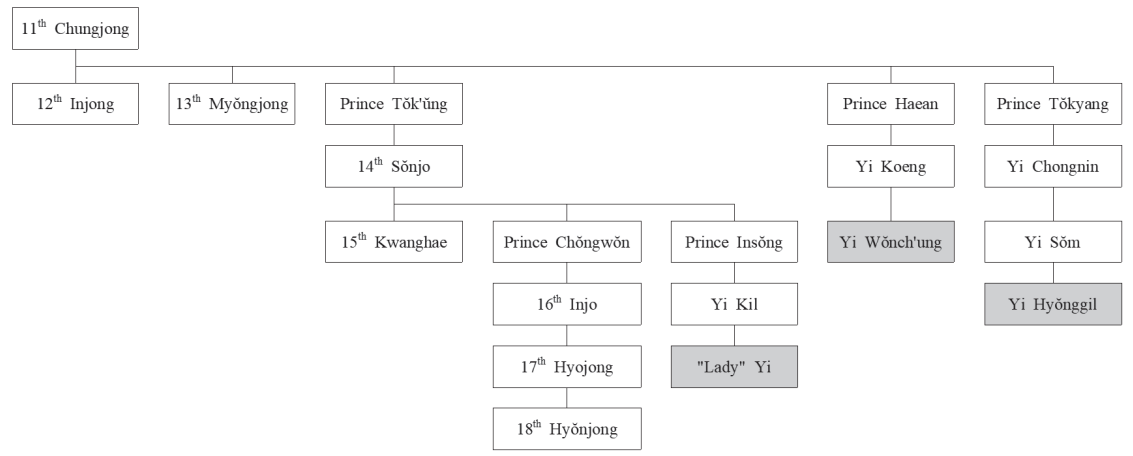

Figure 3 Family tree of the royal family members in the Seoul household register of 1663

Note: The ordinal number signifies the king's order, and the shading represents the royal clan members who appeared in the Seoul household register.

of Yangch'ŏlli-kye, was the grandson of Prince Haean and great-grandson of King Chungjong. He and his wife, "Lady" ${ }^{27} \mathrm{Kim}$, lived together with eight nobi. His sons and nephews lived in separate households in the neighborhood.

The kings of the Chosŏn dynasty, wanting to maintain their political power, banned other royal family members from taking part in politics unless they were at least four generations removed from the king. Instead, they received salaries from the government and sometimes enjoyed special treatment. Yi Wŏnch'ung, who was 67 years old at the time of the 1663 register, was honored with a new noble title in 1676 by King Sukchong in celebration of his 80th birthday. ${ }^{28}$ The king also granted a special award on Yi Wŏnch'ung's 90th birthday, ${ }^{29}$ and when he died in 1693, the whole government honored his death by taking a day off. ${ }^{30}$

Living as a royal family member was not an easy task, as many obligations followed such status. For example, the family of Yi Wŏnch'ung had a bad reputation in the eyes of the public, because they had failed to maintain their dignity and decorum as a royal family. Wŏnch’ung’s son, Sunsŏng, was accused of inappropriate behavior by the Ministry of Punishment in 1679 . The government had organized a praying ritual for rain in response to severe droughts, and Sunsŏng attended this ritual as one of the representatives of the royal family. However, he was imprisoned, ${ }^{31}$ because he broke the sacrificial purification rules of the sacred ritual and worse, he was caught smoking at the place where the ritual was held. ${ }^{32}$

Some royal family members suffered from financial difficulties due to their lack of a government salary. This was true of Yi Yanghŏn, a great-grandson of Prince Haean. In 1671, the Office of the Royal Clan, a department that manages 
the royal family, reported to the king that Yanghŏn was begging for money, ${ }^{33}$ and reported again in 1677 that his clothes were especially tattered. ${ }^{34}$ As a result, the king granted Yanghŏn money to buy food and clothing on two occasions. The household register of 1663 recorded that Yanghŏn was living in Chŭngsalli-kye with his wife and 20 nobi, so it is unclear exactly how his financial situation had become so dire in eight years. The 20 nobi, perhaps, were not enough private property to live in the capital city among other dignified royal clansmen. The economic situation of these royal family members can sometimes be gauged by the number of nobi reported to be in their household on the register.

Royal family members were often at risk of danger during political uprisings and rebellions. "Lady" Yi, the wife of Yi Hwan in Marhŭlsan-kye, was not marked as a royal clansman on the household register, even though she was the great-granddaughter of the 14th king Sŏnjo and granddaughter of Prince Insŏng. She was the closest identifiable family member of King Hyŏnjong (1659-1674), in this particular household register. However, the family of Prince Insŏng and his son, Yi Kil, had suffered adversities because Prince Insŏng became involved in treason. Prince Insŏng had a close relationship with his half-brother, the 15th king, Kwanghae. The coup that took place on 11th of the fourth lunar month of 1623 , in the name of the next king, Injo, subsequently changed the lives of both him and his family. The rebellion dethroned King Kwanghae, who was close to Prince Insŏng, and his nephew, Prince Nŭngyang, became the new king, King Injo. In the eleventh lunar month of 1624, two years after the new king ascended to the throne, a rebellious plot by those supporting the ousted king was discovered. As they planned to install Prince Insŏng as a provisional king until they brought King Kwanghae back from Cheju Island where he was living in exile, the government regarded Prince Insŏng as part of the rebel force. Prince Insŏng was eventually exiled in the second lunar month of 1625, and in the fifth lunar month of 1628, the new king ordered him to commit suicide.

Following Prince Insŏng's death, the new king exiled all of the prince's family to Cheju Island. Fortunately, in the third lunar month of 1629, the king ordered the release of women and children among those who were exiled. It seems that the "Lady" Yi was born on Cheju Island in 1630. Moreover, five years after Prince Insŏng’s death, in 1633, Yi Kil, the son of Insŏng, was finally released and returned to Seoul.

In the fourth lunar month of 1644, ten years after her father, Yi Kil, had already returned to Seoul, King Injo released the "Lady" Yi from her oppressed status. Born to Yi Kil and a nobi, who belonged to the local government of Cheju Island, "Lady" Yi was also accordingly owned by the local government until 1644, following her mother's nobi status. By the king's order, she could leave Cheju Island once she 
turned fifteen to reunite with her father, who left when she was three. However, her mother had to remain on Cheju Island according to the laws regarding nobi. Considering the average marriage age at the time, we believe that she married a person called Yi Hwan within three to four years of her return to Seoul. ${ }^{35}$ Despite her status as the great-granddaughter of the 14th king, Sŏnjo, and second cousin of the 17th king, Hyojong, due to her grandfather's charge of treason and her mother's low status, her family was forced to choose her spouse from an undignified family.

It is likely that the reason why the distant relatives of the king are still recorded in the Seoul register of 1663 as residing in the capital, despite their poor financial circumstances, is that the government was sponsoring them. The reputation of the kings and royal family members had been damaged by the Imjin War and the Manchu invasions. As a result, it is likely that the government sought to maintain the status of these royal clansmen, and thus to maintain the authority of the royal family. In the Confucian preference given to family, solidarity and intimacy among kin members is a crucial concept, so the status of royal family members was directly related to the authority of the king. Korean kings used to compile royal genealogies when they felt they needed to strengthen their political power; for instance, the government published a royal genealogy in $1681 .^{36}$ The information recorded about royal family members in the registers suggests that the government was attempting to maintain royal authority by appearing loyal to royal kin, despite their poor circumstances and fallen status.

\section{Bureaucrats and Eunuchs}

The household registers of 1663 included some bureaucrats and the descendants of famous politicians who resided in the northern district of Seoul. This area was home to former bureaucrats and their families rather than incumbent officials, since these residences were half-a-day's trip away from the palace and the main governmental offices. In Hapchangni-kye, another "Lady" Yi, the wife of An Tukŭk and great-granddaughter of Yi Sanhae was recorded in the 1663 register. Yi Sanhae was a Chief State Councilor, the highest post (senior first rank), in Chosŏn officialdom and led the Greater Northerner (大北) faction in the late sixteenth century. The wife of Sŏ Tongik, yet another "Lady" Yi, lived in Chŭngsalli-kye and was the granddaughter of Yi Tŏkhyŏng, who was also a Chief State Councilor in the early seventeenth century. Yi Tŏkhyŏng was delegated to the Ming Dynasty when the Japanese invasion of Korea broke out and arranged the dispatch of Ming troops into the Korean Peninsula in 1592. Furthermore, Yi Tŏkhyŏng was a son-in-law of Yi Sanhae, making these two "Lady" Yi’s second cousins. 
In the 1663 household register, we occasionally see collective residential arrangements. Collective residences of a family are identified only for royal family members and bureaucratic families. For example, a household head in Segyori-kye, Yi Cha, is listed in the occupational records as a former magistrate of Kŭmsŏng (the junior fifth rank). In his household, there were 57 nobi along with his wife, "Lady" Im, his son, and his daughter-in-law. Another household head, Yi Ŏnch'ŏl, was also a former magistrate of Ŭmjuk (the junior sixth rank). Four additional households in Segyori-kye were comprised of relatives. The household heads Yi Wŏnch'ŏl, and Yi Ŏnch'ǒl were the sons of Yi Cha. An additional, household head, Yi Wi, was the son of Wŏnch'ŏl and grandson of Yi Cha. Each of their households were comprised of their respective wives and sons. This case is the only example in the Seoul register of 1663 of several households of a family living collectively. In rural areas, collective living in consanguineous villages with dozens of households having the same family name appear from the seventeenth century and became common by the late eighteenth century. However, due to high living costs in Seoul, only the wealthy and those who held government offices lived in the capital city and could live together.

Yi Cha's family, amongst whom there were no government officials at the time, sought good fortune by waiting near Seoul for the chance to obtain a governmental post. In order to cover their living expenses, they relied on the labor force of many nobi. This family, a total of four households, possessed 157 nobi; however, among them, only 69 nobi actually cohabited with Yi Cha's family. The other 73 nobi, those who resided in other locales, completed their duties by offering some tribute to their master and his family. It seems that these nobi who lived elsewhere supplied a large portion of the family's living expenses. In addition, the household register recorded that 15 nobi had already fled the family's service.

In order to maintain luxurious lives in the capital, elite families owned a large number of nobi. The household possessing the largest number of nobi in the northern Seoul register was that of Sin Tuching and his wife "Lady" Yi in Mangwŏnjŏng-kye. In total, they possessed 201 nobi, but the household register recorded that only 15 nobi were actually living with their master, and that the other 166 resided in other cities and areas outside of Seoul. The register also records that 20 of Sin Tuching's nobi had fled his service.

One additional demographic that can only be found in Seoul were the eunuchs. The Chosŏn government itself was permitted by law to keep 140 eunuchs to manage the royal palace and carry out duties on behalf of the royal family, but in practice, there were always more than 300 eunuchs. Chosŏn eunuchs were unable to participate in politics, unlike Ming Chinese eunuchs. ${ }^{37}$ In return for this disenfranchisement, Chosŏn eunuchs enjoyed the privilege to have a wife and a family 
outside of the palace, unlike their Chinese counterparts. In the Seoul household register, we can find eight eunuchs recorded as household heads, four of whom had a wife. Although, of course, none of these eunuchs lived with any natural descendants. A certain woman "Lady" Kim reported herself to be the wife of a deceased eunuch named Yun Isin. Her father, grandfather, and great-grandfather were all government officials, so it is apparent that she belonged to the elite class, but it is not clear why she or her family approved of her marriage to a eunuch. Interestingly, all eight eunuchs and their wives had elite family backgrounds.

The register also reveals a eunuch family with the highest official rank among those included in the register. This family was headed by one Chu Pin, who lived with his wife, "Lady" Yun, in Kajwadong-kye. He was in charge of managing the lights of the palace (the junior sixth rank). Although he did not make his mark in the political world, he lived the life of a dignified bureaucrat, commuting to the palace daily and possessing ten cohabiting nobi. The Seoul register of 1663 shows that, unlike the better-known example of Chinese eunuchs, Korean eunuchs were allowed to reside outside the palace, and to marry. ${ }^{38}$

\section{Administrative and Military Cities: Taegu and Ulsan}

Kyŏngsang province is located in the southeastern part of the Korean Peninsula, one of the eight provinces of the country, and suffered the most damage during the Imjin War due to its geopolitical position on the coast facing Japan. The opening and closing stages of the war took place in this province, specifically in the cities of Taegu and Ulsan. As a result, human and material damage caused by the war with Japan continued to be felt into the early seventeenth century. During the nationwide postwar rehabilitation, Taegu was chosen as the provincial capital and emerged as the center of administration and finance among the 72 counties that made up Kyŏngsang province. ${ }^{39}$

Among the eight provinces of the Chosŏn Dynasty, one or two army headquarters ("left" and "right" for east and west), were established in each province except Hwanghae and Kangwŏn, which were in the central part of the Korean Peninsula. In the case of Kyŏngsang, two army headquarters were established to control the east and the west, respectively. In Ulsan, the Headquarters of the Left (east) Kyŏngsang Provincial Army Commander (Kyŏngsang chwado p’yŏngma chŏldosa-yŏng, 慶向左道兵馬節度使營), was established to defend the eastern part of Kyŏngsang Province. The characteristics of Ulsan as a military hub can be seen during the Japanese Invasion of Korea in 1592. During the war, the Japanese built fortresses from Sunch'ŏn in Chŏlla to Ulsan in Kyŏngsang along the southern coast of the Korean Peninsula. Ulsan was one of the major areas 
where such defense facilities were located and was also the last stronghold of Kato Kiyomasa. ${ }^{40}$

Despite being the provincial capital, Taegu was not the political and cultural center of the province. The main geopolitical advantage of Taegu was that travelers had to pass through it when headed from the southeast coast to the capital city of Seoul. As we will see, this background is reflected in the information available about individuals and families recorded in the household register for this province. Likewise, Ulsan was considered one of the hardest-hit areas during the war against Japan. As the Japanese troops invaded and attempted to conscript local people into labor, many men and women were abducted to Japan. Due to its proximity to the coast, Ulsan had also been a target for Japanese pirates in the previous centuries. For that reason, the Chosonn Dynasty, as well as all other former dynasties, had located military facilities in Ulsan to protect the country from Japanese threats. As described below, the household registers of Ulsan show what policies had been implemented to rebuild the country and its community during the postwar period. A lot of human and material resources would have been needed for post-war recovery, and in the household registers we can find evidence of government policies such as the granting of certain occupations and forced migration.

\section{Taegu: Local Civil and Military Officials and Hangwae}

Sŏsang-myŏn, an administrative hub of Taegu in the seventeenth century, has a household register dating back to 1681 and 1684. The household register of Taegu is the most extensive, and most detailed collection among the existing pre-modern Korean household registers. Each one of the 187 books published between 1681 and 1876 includes the corresponding year's statistics (toisang, 都已上), and a record of the Buddhist monks' population (sŭngho, 僧戶), for the major temples in the area. The Taegu household register of 1681, the earliest available, covers 4,005 households and 22,090 people. Taegu county ( $p u$, 府), had about 30 subordinate administrative districts called myŏn (面), or townships under its jurisdiction and one was Sŏsang-myŏn. The household registers in Taegu are considered a good source for historical research, because records for other townships in Taegu are also extant and offer comparison.

Sŏsang-myŏn was in the center of Taegu and was also an area where the kamyŏng (監營), the administrative headquarters for all of Kyŏngsang province, was established. As a result, lower-level local government officials, both civil and military, ${ }^{41}$ and their families comprised a larger portion of the population in Sŏsang-myŏn compared to other regions. It was also common for yangban to live in areas with access to suburban arable land, such as Taegu. 
Despite the fact that more than 80 years had passed since the war with Japan, traces of hangwae (Japanese defectors, 降倭), ${ }^{42}$ who settled during or after the war with Japan were also found in the Taegu household registers. While most individuals and families adopted the "last name, first name and title of clan origin" according to the Chosŏn custom, others were given names that implied their Japanese descent after the Imjin War. A potential reason for this differentiation was the lower social and cultural status of Japanese who were forced to surrender or remain as prisoners of war in Chosŏn territory.

The most famous and socially successful hangwae in Chosŏn was Sayaga. His real name and rank before the surrender are pointed out by many researchers as unclear, but his descendants still recognize him as the first general to lead some 3,000 Japanese troops to surrender to Chosŏn during the Imjin War. He was given a Korean name-Kim Ch'ungsŏn-and a clan origin or pon'gwan: Sasŏng Kimhae, making him a Kimhae Kim. There are debates surrounding his actual Japanese name and place of origin, but he is one of the few examples of Japanese immigrants who left behind their life in Japan. In his later years, Kim Ch'ungsŏn was awarded a new official rank by the government for defeating militant hangwae units during the military coup that broke out in $1624 .{ }^{43}$ This new rank allowed his descendants to obtain and preserve their status as local elites in the Taegu area, despite the fact that Kim Ch'ungsŏn was from Japan.

Aside from the Kimhae Kim, the families of An and Hwang in the Taegu household registers are also believed to be Japanese as demonstrated by their job title as recorded in the registers: hangwae poin (Japanese defector's provisioner, 降倭保人). Of course, the poin, which was one of the occupation titles on the register may not have been directly related to the hangwae, because poin means a person who financially supports those with a particular occupation. However, looking at the differentiation and continuity of households in Ulsan hangwae families, many occupation titles were combined with the word hangwae and they probably show a kinship relationship on the paternal or maternal side with hangwae.

\section{Ulsan: Manchus (Jurchen), Hangwae, and Cheju Islanders}

The Ulsan household register of the seventeenth century indirectly conveys the experience of the Imjin War in this area. Only the household register of 1609 remains, compiled ten years after the war ended. This register records 4,104 people living in 1,244 households in nine townships of Ulsan. Herein, we can see entries on Jurchens, Japanese defectors, and Cheju islanders. 
There are records of individuals and families with the place of origin given as Taewŏn (大元), which means they were originally from Heilongjiang (黑龍江), meaning the Mongol Empire. The occupational record identifies these families as hyanghwa (向化), which means a naturalized resident. ${ }^{44}$ Many Manchurian family names appear in communities on the east coast of the late Chosŏn Dynasty. Ulsan needed a lot of foreign people to recover from the population damage caused by the Imjin War. Foreigners served an economic purpose, because the movement of people and goods was actively carried out along the sea lanes on the east coast of the Korean Peninsula. The Jurchen people, who are often regarded as an equestrian tribe in Manchuria, continued to move by boat along the Tuman (Tumen) River and down the east coast of the peninsula.

After the household register of the seventeenth century, the continued residence of these people and their families is not clear. The reasons for this uncertainty lie in Manchu victories against Chosŏn in 1627 and 1636-37, the construction of the Qing Empire in 1636, and the subsequent demand for repatriation of "Chinese" and Manchurian people, including the Jurchens. In fact, a large number of Manchurian people lived across the border inside Korea before the Japanese and Manchu invasions. Some of them relocated to Korea's southern coastal areas and mountainous areas during the chaos of the seventeenth century. Nevertheless, Manchurian individuals and their families generally disappeared from the Ulsan records by the late seventeenth century, but certain people still carried signifiers of origin. ${ }^{45}$

The 1609 Ulsan household register also records Japanese who surrendered or who were prisoners of war under the signifier hangwae (defecting Japanese). All the hangwae were given Korean-style last names and first names, and most of them were recorded as family units with Korean wives. Looking at their occupation on the registers, one can see that they were tasked with the duties of lower military officers or lower officials in local military bases. The government provided policy support to encourage marriage with Korean wives to help the hangwae lead stable lives and form families to settle down in the region. Behind this policy, support was a strategy to protect Korea from a possible Japanese reinvasion of Chosŏn by using the military capabilities of the hangwae for defense. There are cases of hangwae families surviving until the nineteenth century.

For example, Sin Shiro (信時老), a hangwae, was recorded as a household head in Pumrŏ-ri, Puk-myŏn, Ulsan, in the 1609 register. According to additional information in this entry, he served under a Chosŏn army command from the fourth lunar month of 1594 in a designated hangwae unit. In 1609, Sin Shiro was 53 years old and married to a 40-year-old Korean commoner whose parents had died during the war when she was a minor living in Chŏlla Province. Sin Shiro's 
real Japanese name is unknown, but it seems that he chose a similar pronunciation when he surrendered to the Chosŏn Dynasty after being captured; his Korean name, Shiro (時老), is very similar to a popular Japanese name, Shirō (四郎), which means “the fourth son in a family.” The register shows that his descendants gradually developed their family names and lineages in the custom of the Chosŏn people and discarded the hangwae title. Some even adopted the title yuhak (Confucian student without rank or office, 幼學), which indicates that they were minor, local elites in Korean society.

The household registers of Ulsan recorded people in various social strata who came from other areas of Kyŏngsang Province. Among them, Cheju islanders have a unique record. Firstly, they recorded their actual birthplace on their family register. If an individual moved from Chŏlla Province or Kangwŏn Province to Ulsan, this fact was recorded. Secondly, specific occupational titles were assigned to them.

Like hangwae and hyanghwa, Cheju islanders were given the title tumoak (豆毛惡), to symbolize their ancestors. The occupational title tumoak refers to Mt. Halla, the highest mountain on Cheju, which can be seen from any location on the island. Those who moved to Ulsan from Cheju Island after the war were relocated by the government to augment the national tax collection system. Cheju residents, who specialized in diving and fishing, seem to have migrated from the central area of the island to the coast in order to revive their economic and social status after the war. The residential distribution of Cheju people and their families border the beaches of Ulsan, which suggests that they had been given work related to fishing and collecting shellfish.

The use of the occupational title tumoak, which specifies that the Cheju individual originated from a Cheju Island ancestor, not only indicates that these people specialized in fishing but also that the government needed to clarify their lineage. The government managed people of clear foreign origin, such as hangwae and hyanghwa, but Cheju's position was ambiguous. Cheju Island had been a part of Korea's history since the Koryŏ Dynasty, but islanders had generally ruled the island. From the establishment of the Chosŏn Dynasty, the island was divided into three regions, each of which was subordinate to an administrative unit in Chŏlla Province. Central control of Cheju Island was strengthened only after government officials were dispatched from Seoul to rule. Therefore, individuals and families, who were descendants of hangwae, hyanghwa, and tumoak, initially needed to be classified and recorded in the household register. However, the household registers of the eighteenth century no longer show these signifiers, which causes foreign family names to blend in with the names of ordinary Koreans. The changes were a feature of the eighteenth century, when the Chosŏn government had 
recovered from the war and had re-imposed centralization and a Neo-Confucian governing ideology throughout the country. Thus, foreigners who moved to Kyŏngsang Province during the wars with Japan and the Manchus were given records to identify that they were from abroad.

In the household registers of Taegu and Ulsan, we found that the Chosŏn government singled out heterogeneous residents, such as immigrants, by giving them unique occupational records: hangwae, hyanghwa, tumoak. This kind of distinction in the registers is arguably rooted in the Sino-centric view of Confucianism, which was based on a hierarchy of countries and ethnic groups according to their distance from the center of Confucian civilization, that is, from the Chinese emperor. During the Imjin War, Chosŏn accepted numerous Chinese and Japanese soldiers, who settled in Korea. The government called the Japanese hangwae (meaning "Japanese defector"), with unique signifier, whereas Chinese settlers were not distinguished from Korean people. Giving the Japanese a particular signifier, while marking a former enemy whose loyalty may be in question, indicates that the classifying system of the occupational record was based on Sino-centrism. However, from the late seventeenth century onwards, such records were deleted or changed in the household registers. Does this indicate a weakening of Sino-centrism or a prioritization of other needs? It seems that the immigrants were easily assimilated into Korean society, because they were required to pay the same taxes as ordinary people, such as military service. Equality of taxation derived from the needs of the public sector fisc and was a more important social and national standard in defining individuals. The resulting effect of assimilation came then from the greater needs of taxation and not from the far less important need to specify ethnic origin or other distinction.

\section{Rural Areas: Tansŏng, San'ŭm, Ich'ŏn, and Haenam}

Until the 1970s, most of the Korean Peninsula was rural. Although rural areas had long been marginalized from political power, they were in charge of the production of the most important products: food and people. One of the essential features of pre-modern Korean rural areas was that all residents, elite yangban down to unfree nobi, lived together in villages without distinguishing different districts for each class. In this section, we describe a situation in which rural elites, special occupation workers, and nobi lived together in blended communities.

Tansŏng and San'ŭm were small counties in Kyŏngsang Province, located at the foot of Mount Chiri, the largest mountain in the southern part of the Korean Peninsula. Both small counties had suffered greatly during the Japanese invasions of Korea. Despite being rural, the areas produced examination passers and 
bureaucrats continuously, filling both prefectures with a strong class of local elites. The registers of Tansŏng and San'ŭm, the oldest in existence, have drawn the attention of many scholars. Notably, the Tansŏng register was chosen for the first digitization among all the Chosŏn household registers because it was in excellent condition. Overall, the household register of 1606 Tansŏng covered part of the county and recorded 1,610 people in 219 households.

Ich'ŏn county is a typical rural area situated among the mountains. Although the household register of Ich'ŏn county was published in 1687 (almost 90 years after the Imjin War), it is one of the oldest existing registers in Kangwŏn Province. ${ }^{46}$ Unlike the southern part of the country, the local elites of Ich'ŏn were not powerful enough to control local society, because central government officials or descendants of influential politicians in this region were rare. Therefore, the majority of the residents were commoners and descendants of elites who had fallen on hard times.

Haenam county, located in the southwestern tip of the Korean Peninsula, was a strategic place for the military. The government utilized Haenam as a place of exile, reflecting its distant geography as the farthest place from the king but still on the peninsular mainland. Famous philosophers, such as Chŏng Yakyong (1762-1836), and the painter Kim Chŏnghŭi (1786-1856), were exiled there. The government also established the Naval Command of Right Chŏlla Province in Haenam in 1464. The 1639 register of Haenam covered rural areas far away from where the Naval Command was located, and the demographics collected were not much different from other rural areas. Because many influential families founded their farms in Haenam, there were also many nobi there who belonged to powerful masters, and we will mainly focus on them in this section.

\section{Local Elites}

Kwŏn Che, a government official, lived in Tosaeng-ri at the time of the Tansŏng household register in 1606. The register records that he passed the state civil service examination in twenty-third place out of 34 successful candidates in 1591 and started his career from the sr. ninth rank, the lowest rank within the central government. He returned to his hometown in Tansŏng after one year to organize voluntary patriotic guerilla forces against the invading Japanese. According to his epitaph, he was appointed as the Assistant Section Chief of the Ministry of Works (jr. fifth rank), in $1604,{ }^{47}$ owing to his several victories against the Japanese troops during the war. ${ }^{48}$ After serving as the magistrate of Kobu county, he died in 1611.

Even though Kwŏn Che was an elite bureaucrat who passed the civil service examination, according to the Tansŏng register of 1606, he became destitute after 
the war. The Tansŏng register recorded that he lived with his wife, "Lady" Yi, and 20 nobi. The register noted that 5 nobi had become captives during the war, and 6 out of his 20 nobi had fled. However, it is also likely that those who were reported as "fled" may in fact have died or disappeared in the chaos during and after the war. As a result, in the 1606 register most of his nobi were those who were too old to flee or to be worth taking prisoner. ${ }^{49}$

The Tansŏng household register also indicated that an Administrative Assistant to the Government Arsenal, Kwŏn Sein, lived with two sons in Shindŭng-ri, Tansŏng prefecture in 1606. The only historical record of Kwŏn Sein is a report from 1604, which explains that when he was a magistrate, he was reported to the king for fighting with a friend who lived with him, causing the king to eventually discharge him from his official position. ${ }^{50} \mathrm{He}$ was famous not for his career, but because both of his sons passed the civil service examination, a difficult feat especially for people located in rural areas. The first son, Kwŏn Chip, passed the civil service examination in 1612, and the second son, Kwŏn Chun, passed in 1613. From that point forward, the family became notable in their community.

The financial situation of the family, however, was marred by poverty. They are recorded as having only 6 nobi, one of whom had already fled. The family seemed to have spent all their fortune to educate both sons. Fortunately, the investment was successful in this case. The Tansŏng household register of 1678, the next extant register following 1606, recorded the household of Kwŏn Ki, one of Kwŏn Sein's five grandsons. In 1678, Kwŏn Ki possessed 12 nobi, including 3 nobi who had fled. Thus, it is clear that passing the civil service examination and holding a governmental position helped improve the family's economic situation.

The San'ŭm household register of 1606 includes another successful candidate of the civil service examination. Pak Munyŏng passed the lower civil service examination in 92nd place out of 100 successful candidates on the 29th day of the tenth lunar month of 1606. It is safe to assume that the household register was published after he passed the civil service examination. At the time of the register, Pak Munyŏng was living with his mother, wife, and six nobi, five of whom were on the run. Although he passed the sokwa or lower civil service examination, it seems that he did not attempt the taekwa or higher civil service examination, ${ }^{51}$ and the household's economic situation must have affected the decision. He was enshrined in the local private school after his death by local elites, even though he never held any official position.

There were not many elite families in Ich'ŏn, and their status in their local area was vulnerable. Indeed, there were no successful civil service examination candidates in the Ich'ŏn household register of 1687. In fact, Ich'ŏn failed to produce a single successful candidate for the civil service examination over the 
entire Chosŏn Dynasty. This lack of achievement contrasts with the much smaller counties: 40 successful candidates from Tansŏng and eight from San'ŭm.

Yi Yŏwŏn was one of only a handful of government officials included in the Ich'ŏn household register of 1687. Yi was superintendent of a royal tomb, a post of the lowest official rank (jr. ninth rank), and was tasked with guarding and taking care of the tomb of the sixth king, Tanjong, who was dethroned and murdered in 1457 by his uncle, who later became King Sejo. The later kings, who were descendants not of Tanjong but of Sejo, had treated Tanjong as a prince and not a king until 1681. Therefore, Yi Yŏwŏn's post would have been regarded as the least honorable of all the tomb superintendents.

In 1687, the 71-year-old Yi Yŏwŏn must have been busy repairing and managing the royal tomb, which had been abandoned for more than 200 years. He was living in Hasŏ-myŏn, Ijujin-ri with a wife of the same age, one nobi, and a servant who belonged to another person living in Seoul. Although he was one of the few rare bureaucrats in this county, his age, meager salary, and small assets indicate that his life would not have been easy.

The ordinary lives of elite families residing far from the capital and political power tell us that the bureaucracy and hierarchical system of Chosŏn remained important in the household registers even after the invasions. These families preserved their superiority as local leaders by monopolizing governmental posts and the occupational title of "Confucian student" (yuhak), which guaranteed exemption from military service and corveé. There is a mainstream argument that the status system had been weakened by the Japanese invasions, but the cases of Yi Yŏwŏn and others presented here show that the pre-war markers of social status carried over into post-war society. ${ }^{52}$

\section{Low Born, Nobi}

Nobi remained at the bottom of Chosŏn society until the government completely abolished the nobi system in 1894. Nobi belonged to the lowborn class and were usually owned by another person or government office as a source of labor. In this regard, nobi were unfree labor but were different from Anglo-American "slaves," because they were able to have a family, own property, and pay their owners to gain manumission. ${ }^{53}$

The ratio of nobi in the population varied depending on region and time. Haenam, in particular, had a significantly high proportion of nobi relative to other regions. In 1639, 64.1 percent of all households in the Haenam register (a part of Haenam county), were nobi households. This rate is much higher than in any other area: only 49.1 percent of households in the 1663 Seoul register, 39.2 percent in 
the 1678 Tansŏng register, and 12.2 percent in the 1606 Tansŏng register. Another interesting fact is that 54.8 percent of masters of nobi households in Haenam resided in Seoul and the surrounding Kyŏnggi Province. This phenomenon is unexpected because Haenam is often called "land's end," due to its location at the tip of the southernmost part of the Korean Peninsula.

The nobi owners who did live in Haenam were famous and influential people. For example, the owner of the nobi Man'gŭm in Shin-ri in Haenam was Great Prince Insŏng, who was a brother of the 16th king Injo. The nobi Kich'un, who lived in the same village, was owned by Lord Nŭngsŏng (綾城君), Ku Koeng. Ku Koeng’s name is also included in the Seoul household register of 1663 as the grandfather of Ku Hwan's household in Kajwadong-kye (Seoul). Furthermore, Ku Koeng was a brother-in-law of King Injo, because his younger sister had married the king. The nobi who worked for these men would have sent a certain amount of tribute each year to their owners, who lived extremely far away in the capital.

A final case study further reveals that the nobi system of the Chosŏn dynasty greatly differed from "slavery" as it is commonly understood. In fact, some nobi could possess other nobi. In 1606, a new household head in San'ŭm County, Oigok-ri village, one Myŏngch'un, was recorded as a 30-year-old nobi according to her occupational record. The register also records her owner as Kwi-il and his wife as “woman (召史).” However, Kwi-il reported that he was also a nobi belonging to one Song Chŏng, who lived in another county.

\section{Commoners with Unique Occupations}

The household registers recorded the occupations of all males, because the government imposed duties and services on men based on these records, except for nobi, who services belonged to their masters. Most commoners were engaged in agriculture and had their occupation recorded as "soldier" in household registers. Most of these "soldiers" were not real soldiers, but paid military taxes for national defense. However, there were also unique occupations recorded in the household registers, which deserve closer examination.

\section{SULFUR SOLDIERS}

The 1678 Tansŏng register shows a new occupation, "sulfur soldier," that is not seen in the 1606 household register. This occupation denoted artisans and those who were engaged in sulfur-related work. Sulfur was a necessary ingredient to make gunpowder. Beginning in the late fourteenth century, Korea developed gunpowder and weapons to use against Japanese pirates. ${ }^{54}$ However, the Chosŏn government needed to import sulfur from Japan and China because sulfur was not produced in the Korean Peninsula before the late seventeenth century. The 
lack of sulfur remained a challenge for the Chosonn government as they hurriedly sought to train arquebus units to defend against the Japanese threat. ${ }^{55}$

Around the 1670s, the government finally found sulfur in Kyŏngsang Province and set up sulfur mines there. ${ }^{56}$ The new households designated "sulfur soldiers" were the result of the new sulfur mines in Tansŏng county. Among 13 "sulfur soldiers" households, eight households were in Kalchŏn-ri, indicating that the sulfur mines were probably built near this village.

The demand for sulfur soon caused trouble in the local area. The area was deforested as supervisors took control of the mountain and used trees as fuel to extract sulfur. The supervisor even plundered the miners by receiving more than the prescribed amount, in order to amass his fortune and purchase government posts. News of this abuse reached the Chief State Councilor, who eventually suggested that the King close the sulfur mines near Mount Chiri in 1687, just twelve years after opening. ${ }^{57}$ In the 1730 Tansŏng register, however, about ten households continued to be listed as "sulfur soldiers," so it is possible that the mines were still open or were closed after the 1730s.

\section{ABALONE FISHERMEN}

The Haenam household register in 1639 includes an unusual occupation that is not found in other household registers, aside from the household register of Cheju published in 1810:58 "abalone fisherman.” Chŏng Hŭiryang was one such fisherman, as was Naenpok, another household head, and his wife and son. "Abalone fishermen" were engaged in fishing and shell-fishing, however, their most important mission was to catch abalones. Abalone was so precious that counties on the coast had to allocate a certain amount to the king every year. The government also used abalones in diplomatic relations, especially for their relations with the Qing Dynasty, where abalones were hard to find until the Qing occupied the Chinese mainland. ${ }^{59}$

However, it was not easy to obtain abalones, so fishermen would go into the sea and dive for them. The "abalone fishermen" risked various dangers, such as their boats capsizing or goin adrift. Their troubles are apparent from the stories of fishermen who went out to sea to find abalones and drifted to Okinawa, which are recorded in the sillok for $1716 .{ }^{60}$ As a result, being an "abalone fisherman" was considered a tough and humble occupation. The ancestral records of the two household heads in the register were also fishermen, and the registers also show that their children were also unable to escape from this hard and dangerous duty. Therefore, it is safe to assume that these fishermen in Haenam were given this occupational record, because of their duty to the state. 


\section{BUTCHERS}

A few occupations were considered to be among the lowest class of society even though these workers were not nobi. Butchers are the best example. The San'üm register of 1606 included three butchers: Chinnyŏn and Kalkichi in Pugok-ri and Tongi in Mohosan-ri. Butchers were widely regarded as the lowest social group in the Koryŏ dynasty, because Buddhism banned the killing of all animals. This perception continued well into the Chosŏn dynasty; butchers stayed at the bottom of society until the end of the nineteenth century. ${ }^{61}$

\section{MONKS}

Due to the low official regard for Buddhism by the Chosŏn court, monks were also at the bottom of society, though they were not nobi. The San'ŭm register of Sudagok-ri for 1606 reported that 31-year-old Sŏ Ch'ungkap took the tonsure and became a monk in 1592. It is unclear why he chose to become a monk at the young age of 17 . However, it is highly likely that the Japanese invasion that took place in that very year had a significant impact on his life. Although he left the secular world, his life would be impoverished ever after. That was because the government imposed heavy duties on temples and on monks to control the revival of Buddhism. ${ }^{62}$

\section{SHAMANS}

Another necessary, but socially disregarded existence was that of the shaman. Shamans had long served as priests, doctors, entertainers, and musicians in Korean society for thousands of years. ${ }^{63}$ However, the founders of the Chosŏn dynasty officially classified shamans as nobi, but this distinction was not always followed. Their rituals did not fit the ideology of Confucianism, and they were regarded as "lecherous." The Tansŏng household register of 1678 included two shamans: Ch'oe Un and his wife Han'gŭm, who lived in Ch’ŏlsu-ri. Unlike other shamans in Korean history, their occupational records show that they were both shamans and commoners. In particular, the register recorded Ch'oe Un as a "shaman-craftsman-commoner (巫工良人)." Such an occupation had never been reported. It is possible that Ch'oe Un was an artisan who produced iron, given the name of the village, “Iron-Water (鐵水里, Ch’ŏlsu-ri),” or perhaps he was a musical instrument-handler like many other men at the time who provided musical accompaniment for shamans.

The above cases have implications for our understanding of household registers and Korean society of the seventeenth century. According to the occupations in the registers, the government allotted occupations to commoners based upon its labor 
needs. Sometimes these duties were unpleasant and dangerous, but commoners did not have the freedom to choose their occupations. The various corveé duties featured in the household registers of the seventeenth century indicate that the Chosŏn government did not loosen social control in the wake of the Japanese and Manchu invasions. The registers also show that the population in various social classes from royal family members down to nobi and commoners all resided in mixed villages, rather than living in areas divided by status. The fact that elites were able to safely reside in the same neighborhoods as the lower classes, despite not sharing the same corveé labor obligations, indicates that the Confucian civil elite maintained their control of the villages without conflict until the end of the dynasty. Arguably, this was because the authority of the local elite was based in part on the fact that they had led patriotic militia activities against the Japanese and Manchu invasions. ${ }^{64}$ Thus, the invasions had the side effect of strengthening the Confucian social order.

\section{Conclusion}

This study has identified people of various classes and occupations, recorded in household registers of seventeenth-century Korea, which are now more easily available to scholars. These case studies from the period after the Japanese and Manchu invasions show a social hierarchy that survived the Japanese and Manchu invasions, a social hierarchy in which Confucian, Sino-centric elements were strong. We have seen how elites maintained their social status by maintaining their corveé exempt status while continuing to live in the villages and rely on their authority gained as leaders of the anti-Japanese resistance. ${ }^{65}$ The government likewise strengthened its social control by clarifying the status of heterogeneous residents such as hangwae and allotting corveé duties to commoners. The classification of immigrants from outside of the Korean peninsula was ultimately Sino-centric in origin. Even nearly 100 years after the Imjin War, the government distinguished the Japanese and Jurchens from Chosŏn natives and Chinese immigrants. The title hyanghwa (向化, naturalized resident), in the household register, literally meaning "people who defected for civilization," tells us that they were regarded as the beneficiaries of the edification and civilization that resulted from the rule of the Confucian king of Chosŏn.

The seventeenth-century registers remain so few that scholars have paid minimal attention to them. However, the household registers of Korea are some of the most potent sources of historical and demographic information, because they show the lives and family backgrounds of households from the top to the bottom of society, a rare characteristic among pre-modern population registers 
worldwide. Newly digitized Korean household registers will no doubt continue to provide further material for understanding seventeenth-century Korean society in the future.

\section{Notes}

1. This work received funding from the European Research Council (ERC) under the European Union's Horizon 2020 research and innovation program (no. 758347) and the Ministry of Education of the Republic of Korea and the National Research Foundation of Korea (NRF-2019S1A5B5A07106883).

2. Donggue Lee: First author, Senior Researcher, Academy of East Asian Studies, Sungkyunkwan University type209@skku.edu.

3. Sangwoo Han: Corresponding author, Postdoctoral Researcher, Universitat Autònoma de Barcelona, sangwoo.han@uab.cat.

4. Martina Deuchler. The Confucian Transformation of Korea: A Study of Society and Ideology (Cambridge, Mass.: Harvard University Asia Center, 1992); Mark Peterson. Korean Adoption and Inheritance: Case Studies in the Creation of a Classic Confucian Society (Cornell: Cornell University East Asia Program, 1996). A recent thesis shows efforts to establish a Confucian system around the sixteenth century in Korea. See Joon Hur. "The State and Identity Construction in Chosǒn Korea,” Unpublished PhD dissertation (Los Angeles: UCLA, 2019).

5. The best examples of research using digitized household registers can be seen in Hojŏk taejang yŏn'gu t'im (호적대장 연구팀). Tansŏng hojŏktaejang yŏn'gu (단성 호적대장 연구), Seoul, Sŏnggyun'gwan Taehakkyo Taedongmunhwa Yŏn'guwŏn (성균관대학교 대동문화연 구원, 2003).

6. Hamano Kiyoshi (浜野潔). Rekishi jinkō-gaku de yomu Edo Nihon (歴史人口学で読む江戸 日本) (Tokyo: Yoshikawa Kōbunkan, 2011), p. 193. We should note that the purpose of the Japanese registers was different from the Korean or Chinese cases. The shümon aratame cho were the inquisitorial records to ensure that people kept away from Christianity and were kept by Buddhist temples. The Korean household registers were tax records similar to Chinese household registers. However, most of the elites in Chinese household registers, especially in the registers digitized and opened to the public, were eight banner officials in rural areas and not high-ranking government officials. See James Z. Lee and Cameron D. Campbell. Fate and fortune in rural China: social organization and population behavior in Liaoning 1774-1873 (Cambridge: Cambridge University Press, 2007), pp. 196-214.

7. Nobi (奴婢) has commonly been translated as "slaves," courting comparisons with the Atlantic slave trade. However, we use "nobi" without translation, because we find huge differences between Korean nobi and "slaves" in the antebellum American south, as we will show in this study. For the debate in English-language secondary studies over whether nobi were "slaves," see James B. Palais. "A Search for Korean Uniqueness” Harvard Journal of Asiatic Studies 55:2 (Dec. 1995): 409-425; James B. Palais. "Slave Society” Views on Korean Social History 1998: 23-47, and Young-hoon Rhee and Donghyu Yang. "Korean nobi and American Black Slavery: An Essay in Comparison” Millennial Asia 1-1 (2010): 5-39.

8. Kim Kuen-tae. "Eighteenth-century Korean Marriage Customs: The Tansŏng Census Registers" Continuity and Change 20-2 (2005): 193-209; Kuen-tae Kim. "Differing Patterns of Marriage between a City and Villages in 18th century Korea: The Case of Taegu Area” The History of the Family 14 (2009): 69-87.

9. Byung-giu Son and Sangkuk Lee. "The Effect of Social Status on Women's Age at First Childbirth in the Late Seventeenth- to Early Eighteenth-century Korea" The History of the Family 15 (2010): 430-442; Sangkuk Lee and Byung-giu Son. "Long-term Patterns of 
Seasonality of Mortality in Korea from the Seventeenth to the Twentieth Century" Journal of Family History 37-3 (2012): 270-283; Kuentae Kim, Hyunjoon Park, and Hyejeong Jo. "Tracking Individuals and Households: Longitudinal Features of Danseong Household Register Data” The History of the Family 18-4 (2013): 378-397; Hao Dong. "Patriarchy, Family System and Kin Effects on Individual Demographic Behavior throughout the Life Course: East Asia, 1678-1945” Unpublished PhD dissertation (Hong Kong: Hong Kong University of Science and Technology, 2016).

10. The term of 再造 was used in the meaning of being grateful to Ming China (再造之恩, 再造蕃邦). For the idealization of Ming's help during the Imjin War see, Kim Chunsŏk (金駿錫). “Yangnan gi ŭi kukka chaejo munje (兩亂期의 國家再造 문제)” Hanguksa yŏn'gu (한국사연구) 101 (1998): 115-143; Han Myŏngki (한명기). “Imjin waeran shigi ‘chaejojiŭn' ŭi hyŏngsŏng kwa kŭ ŭimi (임진왜란 시기 ‘재조지은’의 형성과 그 의미” Tongyanghak (東洋學) 29 (1999): 119-136.

11. Kim Chinyŏng (김진영) and Ko Yŏngkŏn (고영건). “Chosŏn hugi chŏkchangja sangsok e taehan yŏksa shimnihak chŏk punsŏk (조선후기 적장자 상속에 대한 역사심리학적 분석)" Tamnon (담론) 201 12-1 (2009): 5-26; Chŏng Chiyŏng (정지영). Chilsŏ ŭi kuch’uk kwa kyunyŏl: Chosŏn hugi hojŏk kwayŏsŏng dŭl (질서의 구축과 균열: 조선후기 호적과 여성들) (Seoul: Sŏgang Taehakkyo Ch'ulp'anbu, 2015).

12. Embraced by the upper class, Confucian ethics trickled down to the lower strata of society aided by such practices as community compacts based on Neo-Confucianism. The compact consisted of an association among the members of a community devoted to the maintenance of social order and morality through mutual admonition and exhortation. See JaHyun Kim Haboush. The Confucian Kingship in Korea: Yŏngjo and the Politics of Sagacity (New York: Columbia University Press, 2001). A network of bureaucrats and scholars spread Neo-Confucian compacts to local communities at a rapid pace. Yun Insuk (윤인숙). Chosŏn chŏn'gi ŭi sarim kwa Sohak (조선 전기의 사림과 <소학>) (Koyang: Yŏksa pip’yŏngsa (역사비 평사, 2016).

13. Pak Kyŏngha (朴京夏). “Waeran chik’u ŭi hyangyag e taehan yŏn’gu: Kop’yŏng-dong tonggye rŭl chungshimŭro (倭亂 直後의 鄉約에 대한 研究: 高坪洞 洞契를 중심으로)” Yŏksawa hyŏnshil (역사와 현실) 5 (1987): 93-115.

14. The kyŏl is a unique land measure unit of pre-modern Korea. It is the largest unit in the kyŏlbu system and its square measure varies depending on the amount of output of the land. In 1634, one kyŏl of first grade land in the sixth grade of the land fertility system was 10,809 square meters.

15. In 1611, the third year of King Kwanghaegun's reign, the Secretary of Finance Hwang Shin once mentioned the size of land before and after the war to king to solve the problem of land investigation and tax collection. According to him, the size and variation of land identified in the eight provinces of Chosŏn before and after the war were as follows: 440,000 kyŏl to 110,000 kyŏl in Chŏlla Province; 430,000 kyŏl to 70,000 kyŏl in Kyŏngsang Province; 260,000 kyŏl to 110,000 kyŏl in Ch'ungch'ŏng Province; 110,000 kyŏl to 61,000 kyŏl in Hwanghae Province; 28,000 kyŏl to 11,000 kyŏl in Kangwŏn Province; 150,000 kyŏl to 39,000 kyŏl in Kyŏnggi Province; 120,000 kyŏl to 47,000 kyŏl in Hamgyŏng Province, and 170,000 kyŏl to 94,000 kyŏl in P'yŏngan Province. Chŭngbo munhŏn pigo, vol. 148 Chŏnbugo 8.

16. Injo sillok, 2:33a, [1623/8/4]. The figures from note 12 corroborates this loss and reports 84 percent.

17. Kwŏn T’aehwan (權泰煥) and Sin Yongha (買鏞廈). “Chosŏn wangjo sidae in'gu ch’ujŏng e kwanhan il siron (朝鮮王朝時代人口推定에 關한 一詩論)” Tonga munhwa (東亞文化) 14 (1977): 289-330; Yi Yŏnggu (李永九) and Yi Hoch’ŏl (李鎬澈). “Chosŏn sidae ŭi in’gu kyumo ch’ugye (朝鮮時代의 人口規模推計) I, II” Kyŏngyŏngsahak (經營史學) 2, 3 (1988): 183-210, 137-185; Tony Michell. “Chosŏn sidae in'gu pyŏndong gwa kyŏngjesa (조선시대의 인구변동과 경제사)” Yŏksa wa kyŏnggye (역사와 경계) 17 (1989): 75-107. 
18. Naitō, Shunpo (内藤巂輔). Bunroku keichō no eki ni okeru hironin no kenkyū (文禄・慶長役に おける被虜人の研究) (Tokyo: Tokyo University Press, 1976).

19. Ch’oe Hokyun (崔豪鈞). “Imjin Chŏngyu Waeran ki inmyŏng p'ihae e taehan kyeryang chŏk yŏn'gu (壬辰·丁酉倭亂期 人命 被害에 대한 계량적 연구)” Kuksagwan nonch'ong (國史館 論叢) 89 (2000): 51. Ch'oe claims that the number of captives reached 400,000, however, most historians presume the number was around 100,000. See Min Tŏkki (민덕기). "Imjin Waeran chung ŭi napch'i toen Chosŏn in munje (임진왜란 중의 납치된 조선인 문제)” Imjillan yŏn'gu ch'ongsŏ: Imjillan 7 chugap kinyŏm (壬辰亂研究叢書: 壬辰亂7周甲紀念) (Seoul: Imjillan chŏngshin munhwa sŏnyanghoe, 壬辰亂精神文化宣揚會, 2013), pp. 296-297.

20. Ch’oe, Myŏnggil (崔鳴吉). “I Chin-jedok cha (移陳都督咨)” Chich’ŏnjip (遲川集) volume 17, book 7; Pak Yongok (박용옥). “Pyŏngja ran p’iro-in sok’wan go (丙子亂被擄人贖還考)” Sach'ong (史叢) 9 (1964): 52.

21. The only major household register of the seventeenth century we did not use in this study is the register for Sangju, 1681. The Sangju registers of the seventeenth century are in a particularly bad condition. Damage to almost every page prevents a meaningful compilation of data.

22. E.W. Wagner. “17segi Chosŏn ŭi sahoe kyech’ŭng - 1663 nyŏn ŭi Sŏul pukpu hojŏk ŭl chungshim ŭro (17세기 朝鮮의 社會階層 - 1663년의 서울 北部戶籍을 중심으로)” Chosŏn sinbun-sa yŏn'gu: sinbun kwa kŭ ijong (朝鮮身分史研究: 身分과 그 移動) (Seoul: Pŏmmunsa, 法文社, 1987), pp. 173-194; Cho Sŏngyun (조성윤). “Chosŏn hugi Sŏul chumin ŭi sinbun kujo wa kŭ pyŏnhwa - kŭndae simin hyŏngsŏng ŭi yŏksa chŏk kiwŏn (조선후기 서울 주민의 신분 구조와 그 변화—근대 시민 형성의 역사적 기원)” Unpublished Ph.D. dissertation (Seoul: Yonsei University, 1992); Kwŏn Kichung (권기중). "17 segi Sŏul chumin ŭi kyech’ŭng kujo wa hogu ŭi p’yŏnje yangsang - Kanghŭi 2 nyŏn kyemyo singnyŏn pukpu changhojŏk ŭl chungshim ŭro (17세기 서울 주민의 계층구조와 戶口의 편제 양상—『康熙武年癸印式年北部帳戶籍』을 중심으로)” Sarim (史林) 57 (2016): 169-191.

23. This study uses the digitized data of the Seoul register with help from Professor Kijung Kwon. The register was digitized as a part of his personal project supported by the National Research Foundation of Korea. For more information, see Kwŏn Kichung, "17 segi Sŏul," 2016.

24. Hyŏnjong sillok, 20:54b, [1672/10/30].

25. Son Pyŏnggyu (손병규). “In'gu-sa jŏk ch’ŭngmyŏn esŏ pon hojŏk kwa chokpo ŭi charyo chŏk sŏnggyŏk-17-19 segi Kyŏngsang-do Tansŏng-hyŏn ŭi hojŏk taejang kwa Hapch’ŏn Yi-ssi ga ŭi chokpo (인구사적 측면에서 본 호적과 족보의 자료적 성격-17 19세기 慶向道 丹城縣의

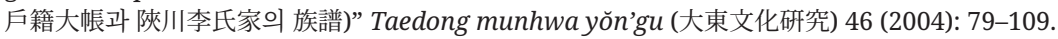

26. Eugene Park's study illustrates the efforts and strategies of the fallen royal families of the Koryŏ dynasty for 500 years. See Eugene Y. Park. A Genealogy of Dissent: The Progeny of Fallen Royals in Chosŏn Korea (Stanford: Stanford University Press, 2018).

27. In Chosŏn household registers, there were three main signifiers for women: "Lady (ssi, 氏),” meaning wife of a yangban; “wife (sŏng, 姓)," meaning wife of a chung'in 中人 or hyangni 鄉吏; and “woman (choi, 召史),” meaning wife of a yang’in 良人 or commoner (sangmin, 常民). Real names were replaced with these signifiers to indicate social class. See Kim Kyŏngnan (김경란). “Chosŏn hugi hojŏk taejang ŭi yŏsŏng hoch’ing kyuchŏng kwa sŏngkyŏk-Tansŏng hojŏk ŭl chungsimŭro (조선후기 호적대장의 여성호칭 규정과 성격—『단성 호적』을 중심으로)" Yŏksa wa hyŏnsil (역사와 현실) 48 (2003): 191-219.

28. Sŭngjŏngwŏn ilgi, Sukchong 2 [1676/5/22, 25].

29. Sŭngjŏngwŏn ilgi, Sukchong 13 [1678/12/15].

30. Sŭngjŏngwŏn ilgi, Sukchong 19 [1693/1/12].

31. Sŭngjŏngwŏn ilgi, Sukchong 5 [1679/7/15].

32. Sŭngjŏngwŏn ilgi, Sukchong 5 [1679/7/14].

33. Hyŏnjong sillok, 19:25b, [1671/5/29]; Sŭngjŏngwŏn ilgi, Hyŏnjong 12, [1671/5/29]. 
34. Sŭngjŏngwŏn ilgi, Sukchong 3, [1677/2/14].

35. The average marriage age of women in the Tansŏng household registers in 1717-1789 was 17.5. Kim, Kuen-tae. "Eighteenth-century Korean Marriage Customs,” 2005, pp. 194-195.

36. King Sukjong was thirteen and King Kojong was eleven when they took the throne. Both kings compiled royal genealogies in order to strengthen their authority by showing the legitimacy and the power of the royal clan. See Kim Sugyŏng (김수경). "17segi huban chongch'in ŭi chungch'i-chŏk hwaldong kwa wisang (17 세기후반 종친의 정치적 활동과 위상)” Yidae sawŏn (이대사원) 30 (1997): 25-63; Kim Ilhwan (김일환), “Chosŏn malgi Sŏnwŏn sokpo palgan kyŏngwi wa chŏngch’i-chŏk ŭimi (조선 말기 璿源續譜 발간경위와 정치적 의미)” Sunchŏn-hyang inmun kwahak nonch'ong (순천향 인문과학논총) 27 (2010): 109-153.

37. Chang Hŭihŭng (張熙興). “Chosŏn shidae hwan'gwan yŏkchech'aek ŭl t’onghae pon wisang pyŏnhwa (朝鮮時代 宦官 抑制策을 통해 본 位相變化)” Tongguk sahak (동국사학) 40 (2004): 283-308.

38. Although we failed to find eunuchs with children in the register, other research has shown that powerful eunuchs adopted heirs. See Chang Hŭihŭng (장희흥), "Yangsegyebo rŭl t’onghae pon chosŏn sidae naeshi ka ŭi kagye kyesŭng (『養世系譜』를 통해 본 朝鮮時代 內侍家의 家系 繼承)” Yǒksa minjok hak (역사민족학) 22 (2006): 243-274.

39. Sŏnjo sillok, 84:13a, [1601/6/17].

40. Sŏnjo sillok, 102:3a, [1598/7/1].

41. For more information about the families of military officers in Taegu, see Yi, Tongkyu (李東奎). “Chosŏn hugi hojŏk sang muim chikyŏg ŭi kyesŭng gwa pyŏndong-Taegu-bu ŭpch’i wa oech’on e kŏjuhanŭn myŏnmyŏt kagyedŭrŭl saryero (조선후기 호적상 무임직역의 계승과 변동—대구부 읍치와 외촌에 거주하는 몇몇 가계들을 사례로).” Taedong munhwa yŏn'gu (大東文化研究) 87 (2014): 33-64.

42. For more information about the Japanese defectors, see: Che Changmyŏng (제장명). "Imjin Waeran sigi hangwae ŭi yuch’i wa hwaryong (임진왜란 시기 降倭의 留置와 활용)” Yŏksa wa segye (역사와 세계) 32 (2007): 95-122; Han Munchong (한문종). "Imjin-ran sigi hangwae ŭi t’uhang paegyŏng gwa yŏk’al (임진란 시기 항왜의 투항 배경과 역할)” Inmun kwahak yŏn'gu (인문과학연구) 36 (2013): 319-349.

43. Sŭngjŏngwŏn ilgi Incho 5 [1627/3/1].

44. More information about Hyanghwa can be found in these articles. Paek Okkyŏng (백옥경), “Chosŏn chŏn'gi hyanghwain e taehan honin kyujŏng gwa yŏsŏng (조선 전기 向化人에 대한 혼인규정과 여성)” Yŏksahak yŏn'gu (역사학연구) 34 (2009): 41-70; Wŏn Ch’angae (원창애). "Hyanghwain ŭi Chosŏn chŏngch'ak sarye yŏn'gu-Yŏjin hyanghwain ŭl chungshimŭro (향화인의 조선 정착 사례 연구—여진 향화인을 중심으로)” Tongyang kojŏn yŏn'gu (東洋古典 研究) 37 (2009): 33-61.

45. We found two women in the Ich'ŏn household register in 1687 who reported their origin as Heilongjiang 黑龍江. The survival of this signifier shows that the system maintained distinctions at least until the late seventeenth century, nearly a century after the Imjin War.

46. Although a register of Kimhwa county in 1672 exists, it is difficult to use for research due to its poor condition.

47. Sŏnjo sillok, 24:669, [1604/intercalary 9/20].

48. Hŏ Yu (許愈). “Chwarang Wŏndang Kwŏn gong myogalmyŏng (佐郎源堂權公墓碣銘)” Husan sŏnsaeng munjip (后山先生文集) volume 16.

49. For more information about the captives in household registers, see Han Sangu (韓相祐). "Imjin waeran p'iroin kwa tohwanin dŭl ŭi hŭnjŏk ŭl ch'ajasŏ—17 segi ch'o hojŏk ŭrobut’ŏ (임진왜란 被擄人과 逃還人들의 흔적을 찾아서-17세기 초 호적으로부터)” Taedong munhwa yŏn'gu (大東文化研究) 110 (2020): 173-200.

50. Sŏnjo sillok, 177:1a, [1604/8/1].

51. Pak Mun'yŏng (朴文楧). Yongho munjip (龍湖文集). Yongho munjip was published in 1862 by descendants of Pak Mun’yŏng. 
52. Yi Changhŭi (李章熙). “Yangban, nongmin ch’ŭng ŭi pyŏnhwa (兩班, 農民層의 變化)” Han'guksa (한국사) 13 (1976): 446-487; pp. 446-459. The Han'guksa series was a part of the Korean History series compiled by the National Institute of Korean History in the 1970s. In a revision published in the 2000s, the tone of argument changed, but there still exists a depiction of confusion in the social hierarchy system. See Yi Chun'gyu (李俊九). “4. Sajok chibae ch'ejeha ŭi shinbun chilsŏ (4. 사족지배체제하의 신분질서)” Shinp'yŏn Han'guksa (신편 한국사) 31 (2002): 132-154.

53. See Rhee, Young-hoon and Donghyu Yang. “Korean nobi and American Black Slavery,” 2010.

54. Kim Kisŏp (金琪临). “Koryŏ hugi Ch’oe Musŏn ŭi saengae wa hwayak chedo (高麗後期 崔茂宣의 생애와 화약제도)” Han'guk chungsesa yŏn'gu (한국중세사연구) 26 (2009): 265-298; Yi Yŏng (李領). “Hongmuje ŭi hwayak·hwap’o chiwŏn kwa Koryŏ sugun ŭi chaegŏn (洪武帝의 火 藥·火砲 지원과 고려 수군의 재건)” Tongbuk Asia munhwa hakhoe kukche haksul taehoe palp'yo charyojip (동북아시아문화학회 국제학술대회 발표자료집) (2016): 216-228.

55. Kwanghaegun ilgi (Kwanghaegun chungch'obon), 50:112b, [1619/8/14].

56. Hyŏnjong sillok, 18:1b, [1670/1/3]; Sŭngjŏngwŏn ilgi, Sukchong 13, [1687/8/12].

57. Sŭngjŏngwŏn ilgi, Sukchong 13, [1687/8/12].

58. For more information about the abalone fishermen, see Kim Nayŏng (김나영). “Chosŏn hugi hojŏk charyo rŭl t’onghae pon pojakŭi sahoe chŏk chiwi (조선후기 호적자료를 통해 본 鮑作의 사회적 지위)” Yŏksa minjokhak (역사민족학) 29 (2009): 107-143.

59. Injo sillok, 28:16b, [1633/3/17]; 29:2a, [1634/1/8].

60. Injo sillok, 43:26a, [1642/10/28].

61. Yi Chun'gu (이준구). “Taehan chegukki tohan (paekchŏng) ŭi hogu yangsang kwa sahoe, kyŏngje chŏk ch’ŏji (대한제국기 屠漢 (白丁)의 戶口 양상과 사회, 경제적 처지)” Taegu sahak (대구사학) 92 (2008): 193-225.

62. Pae Myŏngae (배명애). “Chosŏn chŏn'gi ŭi sung nyŏ t’ongjech’aek kwa sŭngyŏk (조선전기의 승려통제책과 僧役)” Yŏksa wa segye (역사와 세계) 30 (2006): 553-591; O Kyŏnghu (오경후). “Chosŏn hugi pulgyo chŏngch’aek kwa sŏnggyŏk yŏn'gu—Sŏnjo ŭi pulgyo chŏngch'aek ŭl chungshim ŭro (朝鮮後期 佛敉政策과 性格研究—宣祖의 佛敎政策을 中心으로)” Han'guk sasang kwa munhwa (韓國思想과 文化) 58 (2011): 169-193.

63. Yi Nŭnghwa (이능화). Chosŏn musok ko: yŏksa ro pon Han'guk musok (朝鮮巫俗考: 역사로 본 한국 무속) (Paju: Ch’angbi, 2008).

64. Nukii, Masayuki. "Righteous Army Activity in the Imjin War.” In James B Lewis, ed. The East Asian War, 1592-1598: International Relations, Violence, and Memory (London and New York: Routledge, 2015), pp. 141-162.

65. See Chŏng Chinyŏng (정진영). Part 1, Chapters 3 and 5, in Chosŏn shidae hyangch'on sahoesa (조선시대 향촌사회사) (Seoul: Han'gilsa, 1998), pp. 182-196; Martina Deuchler. Part 3, Chapter 9, in Under the Ancestors' Eyes: Kinship, Status, and Locality in Premodern Korea (Cambridge, Mass.: Harvard University Asia Center, 2015), pp. 228-234.

\section{References}

Che, Changmyŏng (제장명). “Imjin Waeran sigi hangwae ŭi yuch’i wa hwaryong (임진왜란 시기 降倭의 留置와 활용) (Enticement and Practical Use of Japanese Soldiers who Surrendered during the Imjin-waeran).” Yǒksa wa segye (역사와 세계) 32 (2007): 95-122.

Ch’oe, Hokyun (崔豪鈞). “Imjin Chŏngyu Waeran ki inmyŏng p’ihae e taehan kyeryang chŏk yŏn'gu (壬辰.丁西倭亂期 人命 被害에 대한 계량적 연구) (A Quantitative Study on Casualties during the Imjin War).” Kuksagwan nonch'ong (國史館論叢) 89 (2000): 35-55.

Ch’oe, Myŏnggil (崔鳴吉). “I Chin-jedok cha (移陳都督咨).” Chich’ŏnjip (遲川集) volume 17, book 7. 
Chang, Hŭihŭng (張熙興). “Chosŏn shidae hwan'gwan yŏkchech'aek ŭl t’onghae pon wisang pyŏnhwa (朝鮮時代 宦官抑制策을 통해 본 位相變化) (Changes in the Status of the Eunuch in the Joseon Dynasty through the Restrictive Systems).” Tongguk sahak (동국사학) 40 (2004): 283-308.

Chang, Hŭihŭng (장희흥). “Yangsegyebo rŭl t’onghae pon chosŏn sidae naeshi ka ŭi kagye kyesŭng (『養世系譜』를 통해 본 朝鮮時代 內侍家의 家系 繼承) (The Lineage Succession of Eunuchs' Family Seen through Yangsekyepo in Chosŏn Dynasty).” Yŏksa minjok hak (역사민족학) 22 (2006): 243-274.

Cho, Sŏngyun (조성윤). “Chosŏn hugi Sŏul chumin ŭi sinbun kujo wa kŭ pyŏnhwa-kŭndae simin hyŏngsŏng ŭi yŏksa chŏk kiwŏn (조선후기 서울 주민의 신분 구조와 그 변화—근대 시민 형성의 역사적 기원) (Caste Structure and Its Change in Seoul During the Yi Dynasty).” Unpublished $\mathrm{PhD}$ dissertation. Seoul: Yonsei University, 1992.

Chŏng, Chinyŏng (정진영). Chosŏn shidae hyangch'on sahoesa (조선시대 향촌사회사) (Social History of the Rural Communities in the Chosŏn). Seoul: Han'gilsa, 1998.

Chŭngbo munhŏn pigo 增補文獻備考 (The Revised and Enlarged Edition of the Comparative Review of Records and Documents).

Deuchler, Martina. The Confucian Transformation of Korea: A Study of Society and Ideology. Cambridge, Massachusetts: Harvard University Asia Center, 1992.

Deuchler, Martina. Under the Ancestors' Eyes: Kinship, Status, and Locality in Premodern Korea. Cambridge, Massachusetts: Harvard University Asia Center, 2015.

Dong, Hao. "Patriarchy, Family System and Kin Effects on Individual Demographic Behavior throughout the Life Course: East Asia, 1678-1945.” Unpublished PhD dissertation. Hong Kong: Hong Kong University of Science and Technology, 2016.

Haboush, JaHyun Kim. The Confucian Kingship in Korea: Yŏngjo and the Politics of Sagacity. New York: Columbia University Press, 2001.

Han, Munchong (한문종). “Imjin-ran sigi hangwae ŭi t’uhang paegyŏng gwa yŏk’al (임진란 시기 항왜의 투항 배경과 역할) (The Background of Hangwae's Surrender and their Roles during the Imjin War).” Inmun kwahak yŏn'gu (인문과학연구) 36 (2013): 319-349.

Han, Myŏngki (한명기). “Imjin waeran shigi ‘chaejojiŭn’ ŭi hyŏngsŏng kwa kŭ ŭimi (임진왜란 시기 '재조지은'의 형성과 그 의미) (During the Japanese Invasion of Korea in 1592, the Formation and Political Meaning of ‘Chaejochiun'.” Tongyanghak (東洋學) 29 (1999): 119-136.

Han, Sangu (韓相祐). “Imjin waeran p’iroin kwa tohwanin dŭl ŭi hŭnjŏk ŭl ch’ajasŏ—17 segi ch’o hojŏk ŭrobut’ŏ (임진왜란 被擄人과 逃還人들의 흔적을 찾아서-17세기 초 호적으로부터) (Finding Imjin War Captives and Returnees in Household Registers of the Early Seventeenth Century).” Taedong munhwa yŏn'gu (大東文化研究) 110 (2020): 173-200.

Hamano, Kiyoshi (浜野潔). Rekishi jinkō-gaku de yomu Edo Nihon (歴史人口学で読む江戸日本) (Edo Japan through the Historical Demography). Tokyo: Yoshikawa Kōbunkan, 2011.

Hŏ, Yu (許愈). “Chwarang Wŏndang Kwŏn gong myogalmyŏng (佐郎源堂權公墓碣銘),” Husan sŏnsaeng munjip (后山先生文集), volume 16.

Hojŏk taejang yŏn'gu t'im (호적대장 연구팀). Tansŏng hojŏktaejang yŏn'gu (단성 호적대장 연구) (Study of the Tansŏng Household Registers). Seoul: Sŏnggyun'gwan Taehakkyo Taedongmunhwa Yŏn'guwŏn (성균관대학교 대동문화연구원), 2003.

Hur, Joon. “The State and Identity Construction in Chosǒn Korea.” Unpublished PhD dissertation. Los Angeles: UCLA, 2019.

Hyŏnjong sillok 顯宗實錄 (Veritable Records of King Hyŏnjong).

Injo sillok 仁祖實錄 (Veritable Records of King Injo).

Kim, Chinyŏng (김진영), and Yŏngkŏn Ko (고영건). “Chosŏn hugi chŏkchangja sangsok e taehan yŏksa shimnihak chŏk punsŏk (조선후기 적장자 상속에 대한 역사심리학적 분석) (A Historical Psychological Analysis of the Primogeniture of Late Chosŏn Dynasty).” Tamnon 201 (담론 201) 12-1 (2009): 5-26. 
Kim, Chunsŏk (金駿錫). “Yangnan gi ŭi kukka chaejo munje (兩亂期의 國家再造 문제) (Discourses on the State Rebuilding in the 17th Century Korea).” Hanguksa yŏn'gu (한국사연구) 101 (1998): 115-143.

Kim, Ilhwan (김일환). “Chosŏn malgi Sŏnwŏn sokpo palgan kyŏngwi wa chŏngch’i-chŏk ŭimi (조선 말기 㕡源續譜 발간경위와 정치적 의미) (Reasons for Publishing Sŏnwŏn sokpo and Political Meaning in Late of Chosŏn Dynasty).” Sunchŏn-hyang inmun kwahak nonch'ong (순천향 인문과학논총) 27 (2010): 109-153.

Kim, Kuen-tae. "Eighteenth-century Korean Marriage Customs: the Tansŏng Census Registers.” Continuity and Change 20-2 (2005): 193-209.

Kim, Kuen-tae. "Differing Patterns of Marriage between a City and Villages in 18th Century Korea: The Case of Taegu Area.” The History of the Family 14 (2009): 69-87.

Kim, Kuentae, Hyunjoon Park, and Hyejeong Jo. "Tracking Individuals and Households: Longitudinal Features of Danseong Household Register Data.” The History of the Family 18-4 (2013): 378-397.

Kwanghaegun ilgi (Kwanghaegun chungch'obon, T'aebaeksanbon) 光海君日記 (光海君中草本, 太白山本) (Veritable Records of King Kwanghae).

Kwŏn, Kichung (권기중). “17 segi Sŏul chumin ŭi kyech’ŭng kujo wa hogu ŭi p’yŏnje yangsangKanghŭi 2 nyŏn kyemyo singnyŏn pukpu changhojŏk ŭl chungshim ŭro (17세기 서울 주민의 계층구조와戶口의 편제 양상—『康熙武年癸印式年北部帳戶籍』을 중심으로) (The Hierarchy Structure and Organization of Households in 17th Century Seoul Korea-A Case Study Based on the “Household Register of Northern Section of Hanyang in 1663”).” Sarim (史林) 57 (2016): 169-191.

Kim Kisŏp (金琪临). “Koryŏ hugi Ch’oe Musŏn ŭi saengae wa hwayak chedo (高麗後期 崔茂宣의 생애와 화약제도) (The Lifetime and Gunpowder Manufacturing of Ch'oe Musŏn in the Late Koryŏ Dynasty).” Han'guk chungsesa yŏn'gu (한국중세사연구) 26 (2009): 265-298.

Kim, Kyŏngnan (김경란). “Chosŏn hugi hojŏk taejang ŭi yŏsŏng hoch’ing kyuchŏng kwa sŏngkyŏk-Tansŏng hojŏk ŭl chungsimŭro (조선후기 호적대장의 여성호칭 규정과 성격—『단성 호적』을 중심으로) (Examining the Tansŏng area Census Register-The Regulations Regarding the Female Designations of the Chosŏn dynasty's latter half period Census Registers, and the Nature of those Designations).” Yŏksa wa hyŏnsil (역사와 현실) 48 (2003): 191-219.

Kim, Nayŏng (김나영). “Chosŏn hugi hojŏk charyo rŭl t’onghae pon pojakŭi sahoe chŏk chiwi (조선후기 호적자료를 통해 본 鮑作의 사회적 지위) (The Social Status of 'Pojak' in the Late Period of Chosŏn Dynasty from 'hojŏk (Census Register data)').” Yŏksa minjokhak (역사민 족학) 29 (2009): 107-143.

Kim, Sugyŏng (김수경). “17segi huban chongch'in ŭi chungch’i-chŏk hwaldong kwa wisang (17 세기후반 종친의 정치적 활동과 위상) (The Activities and Political Status of Chongch'in in the Second Half of the 17th Century).” Yidae sawŏn (이대사원) 30 (1997): 25-63.

Kwŏn, T’aehwan (權泰煥), and Yongha Sin (愼鏞廈). “Chosŏn wangjo sidae in'gu ch’ujŏng e kwanhan il siron (朝鮮王朝時代 人口推定에 關한 一詩論) (On Population Estimates of the Yi Dynasty, 1392-1910).” Tonga munhwa (東亞文化) 14 (1977): 289-330.

Lee, James Z., and Cameron D. Campbell. Fate and Fortune in Rural China: Social Organization and Population Behavior in Liaoning 1774-1873. Cambridge: Cambridge University Press, 2007.

Lee, Sangkuk, and Byung-giu Son. "Long-term Patterns of Seasonality of Mortality in Korea from the Seventeenth to the Twentieth Century.” Journal of Family History 37-3 (2012): 270-283.

Min, Tŏkki (민덕기). "Imjin Waeran chung ŭi napch'i toen Chosŏn in munje (임진왜란 중의 납치된 조선인 문제) (The Issue of Koreans Captured during the Imjin War).” Imjillan yŏn'gu ch'ongsŏ: Imjillan 7 chugap kinyŏm (壬辰亂硎究叢書: 壬辰亂7周甲紀念), Seoul: Imjillan chŏngshin munhwa sŏnyanghoe (壬辰亂精神文化宣揚會), 2013, pp. 276-300.

Naitō, Shunpo (内藤售輔). Bunroku keichō no eki ni okeru hironin no kenkyū (文禄・慶長役における 被虜人の研究) (A Study of the Captives during the Bunroku and Keicho War). Tokyo: Tokyo University Press, 1976. 
Nukii, Masayuki. "Righteous Army Activity in the Imjin War.” In James B Lewis, ed. The East Asian War, 1592-1598: International Relations, Violence, and Memory. London and New York: Routledge, 2015, pp. 141-162.

O, Kyŏnghu (오경후). “Chosŏn hugi pulgyo chŏngch’aek kwa sŏnggyŏk yŏn’gu—Sŏnjo ŭi pulgyo chŏngch'aek ŭl chungshim ŭro (朝鮮後期 佛呚政策计 性格研究一宣祖의 佛呚政策을 中心으로) (A Study on Buddhist Policy and its Character in the Late of Chosŏn Dynasty: Focusing on Buddhist Policy during the King of Sŏnjo’s reign).” Han'guk sasang kwa munhwa (韓國思 想과 文化) 58 (2011): 169-193.

Pae, Myŏngae (배명애). “Chosŏn chŏn'gi ŭi sŭngnyŏ t’ongjech'aek kwa sŭngyŏk (조선전기의 승려통 제책과 僧役) (The Controlled Policy and the Compulsory Labor of Buddhist Monks in the First Half of the Chosŏn Dynasty).” Yǒksa wa segye (역사와 세계) 30 (2006): 553-591.

Paek, Okkyŏng (백옥경). “Chosŏn chŏn'gi hyanghwain e taehan honin kyujŏng gwa yŏsŏng (조선 전기 向化人에 대한 혼인규정과 여성) (Marriage Law for Naturalized People and Women in the Early Chosŏn Period).” Yŏksahak yŏn'gu (역사학연구) 34 (2009): 41-70.

Pak, Mun’yŏng (朴文楧). Yongho munjip (龍湖文集).

Palais, James B. “A Search for Korean Uniqueness.” Harvard Journal of Asiatic Studies, 55:2 (Dec. 1995): 409-425.

Palais, James B. “Slave Society.” Views on Korean Social History (1998): 23-47.

Pak, Kyŏngha (朴京夏). “Waeran chik’u ŭi hyangyag e taehan yŏn'gu: Kop’yŏng-dong tonggye rŭl chungshimŭro (倭亂 直後의 鄉約에 대한 研究: 高坪洞洞契를 중심으로) (The Centering around Kop’yŏng-dong Tonggye-A Study on the Hyangyag after the Imjin War).” Yŏksawa hyŏnshil (역사와 현실) 5 (1987): 93-115.

Pak, Yongok (박용옥). “Pyŏngja ran p’iro-in sok’wan go (丙子亂被擄人贖還考) (A Study on the Repatriation of Captives of the Manchu Invasions).” Sach'ong (史趣) 9 (1964): 51-93.

Park, Eugene Y. A Genealogy of Dissent: The Progeny of Fallen Royals in Chosŏn Korea. Stanford: Stanford University Press, 2018.

Peterson, Mark. Korean Adoption and Inheritance: Case Studies in the Creation of a Classic Confucian Society. Cornell: Cornell University East Asia Program, 1996.

Rhee, Young-hoon, and Donghyu Yang. "Korean nobi and American Black Slavery: An Essay in Comparison.” Millennial Asia 1-1 (2010): 5-39.

Son, Pyŏnggyu (손병규). “In'gu-sa jŏk ch’ŭngmyŏn esŏ pon hojŏk kwa chokpo ŭi charyo chŏk sŏnggyŏk-17-19 segi Kyŏngsang-do Tansŏng-hyŏn ŭi hojŏk taejang kwa Hapch’ŏn Yi-ssi ga ŭi chokpo (인구사적 측면에서 본 호적과 족보의 자료적 성격-17 19세기 慶向道 丹城縣의 戶籍大帳과 陝川李氏家의 族譜) (Korean Household Registers and Clan Genealogies Seen as Demographic Sources: Comparison of Tansŏng Household Registers and Hapch'ŏn Yi Clan Genealogies in the 17th through 19th Century Korea).” Taedong munhwa yŏn'gu (大東文化 研究) 46 (2004): 79-109.

Son, Byung-giu, and Sangkuk Lee. "The effect of social status on women's age at first childbirth in the late seventeenth- to early eighteenth-century Korea." The History of the Family 15 (2010): 430-442.

Sŏnjo sillok 宣祖實錄 (Veritable Records of King Sŏnjo).

Sŭngjŏngwŏn ilgi 承政院日記 (Daily Record of the Grand Secretariat).

Tony Michell. “Chosŏn sidae in'gu pyŏndong gwa kyŏngjesa (조선시대의 인구변동과 경제사) (Fact and Hypothesis in Yi Dynasty Economic History: The Demographic Dimension).” Yŏksa wa kyŏnggye (역사와 경계) 17 (1989): 75-107.

Wagner, E.W. “17segi Chosŏn ŭi sahoe kyech’ŭng-1663 nyŏn ŭi Sŏul pukpu hojŏk ŭl chungshim ŭro (17세기 朝鮮의 社會階層—1663년의 서울 北部戶籍을 중심으로) (Social Stratification in Seventeenth-Century Korea: Some Observations from a 1663 Seoul Census Register).” Chosŏn sinbun-sa yŏn'gu: sinbun kwa kŭ ijong (朝鮮身分史研究: 身分과 그 移動), Seoul: Pŏmmunsa (法文社), 1987, pp. 173-194. 
Wŏn, Ch’angae (원창애). “Hyanghwain ŭi Chosŏn chŏngch’ak sarye yŏn'gu-Yŏjin hyanghwain ŭl chungshimŭro (향화인의 조선 정착 사례 연구여진 향화인을 중심으로) (Some Instances of Manchurian Naturalization and Settlement in Chosŏn Dynasty).” Tongyang kojŏn yŏn'gu (東洋古典研究) 37 (2009): 33-61.

Yi, Changhŭi (李章熙). “Yangban, nongmin ch’ŭng ŭi pyŏnhwa (兩班, 農民層의 變化) (Change of Yangban Elite and Peasants).” Han'guksa (한국사) 13 (1976): 446-487.

Yi, Chun'gu (李俊九). "4. Sajok chibae ch'ejeha ŭi shinbun chilsŏ (4. 사족지배체제하의 신분질서) (The Hierarchical Order under the Ruling System of the Literati).” Shinp'yŏn Han'guksa (신편 한국사) 31 (2002): 132-154.

Yi, Chun'gu (이준구). “Taehan chegukki tohan (paekchŏng) ŭi hogu yangsang kwa sahoe, kyŏngje chŏk ch’ŏji (대한제국기 屠漢 (白丁)의 戶口 양상과 사회, 경제적 처지) (Aspects and Social \& Economic Situation of Tohan (Paekchŏng) during the Period of Taehan Empire).” Taegu sahak (대구사학) 92 (2008): 193-225.

Yi, Nŭnghwa (이능화). Chosŏn musok ko:yŏksa ro pon Han'guk musok (朝鮮巫俗考: 역사로 본 한국 무속) (A Study on Chosŏn Shamanism: Korean Shamanism in History). Paju: Ch’angbi, 2008.

Yi, Tongkyu (李東奎). “Chosŏn hugi hojŏk sang muim chikyŏg ŭi kyesŭng gwa pyŏndongTaegu-bu ŭpch’i wa oech'on e kŏjuhanŭn myŏnmyŏt kagyedŭrŭl saryero (조선후기 호적상 무임직역의 계승과 변동-대구부 읍치와 외촌에 거주하는 몇몇 가계들을 사례로) (Succession and Changes of the Military Occupation on Family Registries in the Late Chosun Dynasty-Case Studies of Some Families Lived in Downtown and Outskirts).” Taedong munhwa yŏn'gu (大東文化研究) 87 (2014): 33-64.

Yi, Yŏng (李領). “Hongmuje ŭi hwayak·hwap’o chiwŏn kwa Koryŏ sugun ŭi chaegŏn (洪武帝의 火 藥·火砲 지원과 고려 수군의 재건) (The Support of Gunpowder and Artillery by Hungwu Emperor of Ming Dynasty and the Rebuilding of the Navy of Koryŏ Dynasty).” Tongbuk Asia munhwa hakhoe kukche haksul taehoe palp'yo charyojip (동북아시아문화학회 국제학술 대회 발표자료집) (2016): 216-228.

Yi, Yŏnggu (李永九), and Yi Hoch’ŏl (李鎬澈). “Chosŏn sidae ŭi in’gu kyumo ch’ugye (朝鮮時代의 人口規模推計) I, II (The Estimation of Population in Choson Dynasty).” Kyŏngyŏng sahak (經營史學) 2, 3 (1988): 183-210, 137-185.

Yun, Insuk (윤인숙). Chosŏn chŏn'gi ŭi sarim kwa Sohak (조선 전기의 사림과 <소학>) (The Literati and Sohak in the Early Chosŏn Korea). Koyang: Yŏksa pip’yŏngsa (역사비평사), 2016. 